\title{
Macroinfauna Dynamics and Sediment Parameters of a Subtropical Estuarine Lake-Coombabah Lake (Southern Moreton Bay, Australia)
}

\author{
Ryan J.K. Dunn ${ }^{\dagger *}$, Charles J. Lemckert ${ }^{\dagger * *}$, Peter R. Teasdale ${ }^{\ddagger}$, and David T. Welsh \\ ${ }^{\ddagger}$ Environmental Futures Centre \\ ${ }^{\dagger}$ Griffith School of Engineering \\ Griffith University, Gold Coast Campus \\ Queensland 4222, Australia \\ Griffith University, Gold Coast Campus \\ Queensland 4222, Australia
}

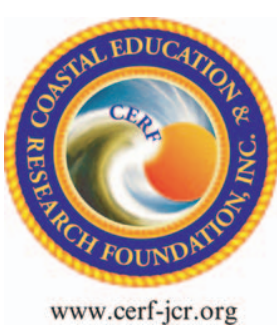

c.lemckert@griffith.edu.au

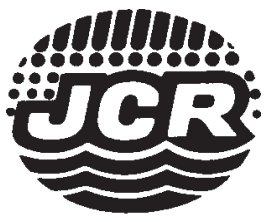

www.JCRonline.org

\begin{abstract}
Dunn, R.J.K.; Lemckert, C.J.; Teasdale, P.R., and Welsh, D.T., 2013. Macroinfauna dynamics and sediment parameters of a subtropical estuarine lake-Coombabah Lake (Southern Moreton Bay, Australia). Journal of Coastal Research, 29(6A), 156-167. Coconut Creek (Florida), ISSN 0749-0208.
\end{abstract}

\begin{abstract}
The distribution, composition, density, and biomass of benthic macrofauna within estuarine environments typically exhibit significant variations attributable to heterogeneity in and interactions between physical, biological, and chemical processes. The spatial and temporal dynamics of benthic macroinfauna assemblages and physicochemical sediment parameters within the intertidal mudflats of a subtropical estuarine lake (Coombabah Lake, Southern Moreton Bay) were studied at four sites from August 2006 to April 2007. No significant seasonal changes were observed at any site for all physical sediment parameters. The northern sample sites were characterised by fine- to medium-grained to moderately to poorly sorted sediments and the southern sample sites by fine-grained to moderately well to well-sorted. A total of 1029 individuals representing species from three orders, including deposit feeding and filter feeding macroinfaunal groups, were collected. The highest combined species densities occurred in the fine-grained southern sites, with the greatest combined species density occurring at Site 4 during winter. Amphipods (Victoriopisa australiensis) and polychaete worms (Simplisetia aequisetis) dominated the lake-wide faunal community with $V$. australiensis, representing $49 \%$ of the total retrieved macroinfauna. Significant correlations between mean macroinfauna densities, biomass ${ }_{\mathrm{DW}}$, sediment parameters, and seasonal maximum monthly temperatures were identified during the study. Seasonal trends in combined site densities were observed at each of the lake sites, with the highest combined density occurring during winter. Spatial and temporal variations might also be partially explained by the predation pressures of fish and migratory wading birds within the lake, with the seasonal presence of migratory wading birds coinciding with the minimum observed macroinfauna densities at each sample site.
\end{abstract}

ADDITIONAL INDEX WORDS: Population dynamics, intertidal sediments, predation.

\section{INTRODUCTION}

Despite ever-changing physical and chemical conditions, estuaries are characterised by high primary productivity (Alongi, 1998; Heip et al., 1995; Kennish, 2002) and concentrations of organic matter (Cifuentes, 1991; Dunn et al., 2008). Consequently, estuarine sediments often support high abundances and biomasses of benthic macrofauna (Moreira, Aldea, and Troncoso, 2010; Snelgrove, 1999), which provide vital food for many crustacean, fish, and shorebird species (Wolff, 1987; Ysebaert et al., 2005). As a result, intertidal habitats are of high conservation value (Fujii, 2007; Kennish, 2002) and often function as nursery grounds for important recreational and commercial fish species (Gray, McElligott, and Chick, 1996; Ysebaert et al., 2005).

DOI: 10.2112/JCOASTRES-D-12-00219.1 received 24 October 2012; accepted in revision 26 February 2013; corrected proofs received 8 April 2013.

Published Pre-print online 1 May 2013.

* Present address: Asia-Pacific ASA Pty. Ltd., P.O. Box 1679

Surfers Paradise, Queensland 4217, Australia

** Corresponding author

(C) Coastal Education \& Research Foundation 2013
The distribution, composition, density, and biomass of benthic macrofauna within estuarine environments typically exhibit significant variations attributable to the heterogeneity in and interactions between physical, biological, and chemical processes. To date, extensive efforts have been made to investigate macrofauna community dynamics and the role of influencing variables, such as hydrodynamic conditions, water depth, sediment composition, temperature, biogeochemical conditions, productivity and primary producer community structure, water column conditions, predator-prey relationships, and anthropogenic disturbances (e.g., Arvanitidis et al., 1999; Jones, Watson-Russell, and Murray, 1986; Kanaya and Kikuchi, 2008; McKindsey, Archambault, and Simard, 2012; Rossi, Castelli, and Lardicci, 2006; Ysebaert et al., 2002, 2003). Furthermore, investigations regarding temporal variations of benthic macrofauna are also of great interest (e.g., Cheng, 1995; Cheng and Chang, 1999; Jones, 1987; Kanaya, Suzuki, and Kikuchi, 2011; Morrisey et al., 1992; Sánchez-Moyano, García-Asencio, and García-Gómez, 2010; Ysebaert and Herman, 2002).

Because of their importance to estuarine food web dynamics and biogeochemical processes (Kristensen, 2000; Welsh, 2003), 
benthic macroinfauna are regarded as a key feature in estuarine monitoring programmes (Ysebaert and Herman, 2002). Through their feeding, burrow construction, bioturbation, and burrow irrigation activities, infauna can influence rates of organic matter inputs to the sediment, the vertical distribution of sedimentary organic matter, rates and pathways of organic matter mineralisation, and the fluxes of the regenerated dissolved nutrients back to the overlying water (Dunn et al., 2009, 2012; Jordan et al., 2009; Welsh, 2003). The extent of these influences depends on the functional groups of animals present and their abundance, biomass density, population dynamics, and individual size (Kristensen, 2000; Welsh, 2003). Therefore, investigations regarding macroinfauna community structure and dynamics are important when formulating models and quantitative predictions about the functioning of soft-bottom marine systems.

The present study investigated the spatial and temporal dynamics of benthic macroinfauna assemblages along with physicochemical sediment parameters within the intertidal mudflats of a subtropical estuarine lake of conservation significance. This work is intended to provide an initial assessment of the benthic macroinfauna assemblages in conjunction with physicochemical sediment and environmental parameters in an attempt to identify relationships and spatial and temporal variations within Coombabah Lake.

\section{Site Description}

\section{METHODS AND MATERIALS}

Coombabah Lake $\left(27^{\circ} 54^{\prime} 33^{\prime \prime} \mathrm{S}, 153^{\circ} 21^{\prime} 07^{\prime \prime} \mathrm{E}\right)$ is a subtropical, semiurbanised estuarine lake, which is part of Coombabah Creek, located in SE Queensland (Gold Coast, Australia) (Figure 1). The lake covers an area of approximately $2 \mathrm{~km}^{2}$; however, despite its modest dimensions, the lake and intertidal surrounds are recognised as a wetland of significant importance under the Convention on Wetlands as part of the Moreton Bay Ramsar wetland (www.ramsar.org/index_list.htm). The site is also an important migratory bird habitat and is listed under the China-Australia Migratory Bird Agreement (1974) and Japan-Australia Migratory Bird Agreement (1986). Furthermore, the lake is a protected fish habitat area (Fisheries Act 1994) and provides a nursery for commercially and recreationally important fish, prawn and crab species. The lake is open to the Gold Coast Broadwater (a barrier island lagoon), through Coombabah Creek, and is subject to a mixed semidiurnal tidal regime with salinity ranging from $\sim 10$ to 33 (Ali, Lemckert, and Dunn, 2010). The tidal and hydrodynamic conditions characteristics of the lake are described by Knight et al. (2008), Ali, Zhang, and Lemckert (2009), and Ali, Lemckert, and Dunn (2010). Annual rainfall for the region is approximately $1400 \mathrm{~mm}$, with intense rainfall events common throughout the summer period. The minimum and maximum mean daily temperatures range from 9.2 to $28.5^{\circ} \mathrm{C}$ during July and January, respectively.

With the exception of shallow channels, Coombabah Lake is characterised by a relatively flat bathymetry, with water depths of 0 to $\sim 1 \mathrm{~m}$ at low water. During periods of low water, large portions of the lake sediments become exposed, which are characterised by mostly fine sediments away from the major drainage channels (Dunn et al., 2008).
The lake supports a mangrove dominated fringing flora, with Casuarina sp. and Melaleuca sp. on areas above the high-tide mark. Grey mangroves (Avicennia marina) form dense stands in low-lying areas connected to the lake in addition to Ceriops tagal, Aegiceras corniculatum, Bruguiera gymnorrhiza, and Rhizophora stylosa found in fringing mangrove stands. The lake edge-mangrove interface is $\sim 20 \mathrm{~km}$ in length, with mangroves extending landward between $\sim 5$ and $700 \mathrm{~m}$ (commonly $\sim 400 \mathrm{~m}$ ).

\section{Sample Collection}

Sediment samples were collected from four sampling sites within Coombabah Lake to determine macroinfauna abundance and biogeochemical properties, representing four regions of different surface sediment particle size distributions, organic matter sources, and hydrological features of the lake (see Dunn et al., 2012) (Figure 1). Six undisturbed sediment cores were collected during low water exposure from each of the four sites during consecutive seasons (winter [August] and spring [November] 2006; summer [January] and autumn [April] 2007) using sediment cores (plexiglass; $20 \mathrm{~cm}$ internal diameter $\times 33 \mathrm{~cm}$ length) for the determination of macroinfauna populations at each site during each season (i.e. total $n=96$ ). Following collection, the sediment cores were transported to a constant temperature laboratory before being placed within a 220 -L holding tank containing aerated site water, maintained under seasonal temperatures. Three additional sediment cores (PVC; $50 \mathrm{~mm}$ internal diameter $\times 400 \mathrm{~mm}$ length) were also collected at each of the four sites during each of the four seasons (i.e. total $n=48$ ) for the determination of physical and biogeochemical parameters. Following collection these cores were immediately sliced into six depth horizons $(0-1$, $1-2,2-4,4-6,6-10$, and $10-15 \mathrm{~cm}$ ) for determination of density, porosity, grain size distribution, organic matter content $\left(\mathrm{LOI}_{550}\right)$, bioavailable ammonium $\left(\mathrm{NH}_{4 \text { bio }}^{+}\right.$; porewater + exchangeable $\mathrm{NH}_{4}^{+}$), and bioavailable phosphate $\left(\mathrm{PO}_{4 \text { bio }}^{3-}\right.$; porewater + exchangeable $\left.\mathrm{PO}_{4}^{3-}\right)$ concentrations. Subsamples of each depth horizon for the determination of $\mathrm{NH}_{4 \text { bio }}^{+}$and $\mathrm{PO}_{4 \text { bio }}^{3-}$ were immediately transferred to sample tubes containing $1 \mathrm{M} \mathrm{KCl}$ and $1 \mathrm{M} \mathrm{MgCl}_{2}$, respectively, and stored at $<4^{\circ} \mathrm{C}$ in the field. All samples were returned to the laboratory within 2 hours of collection and stored at $-20^{\circ} \mathrm{C}$ until analysis.

\section{Sediment Analyses}

Sediment wet-bulk density and water content were determined according to methods outlined by Percival and Lindsay (1997). Organic matter content $\left(\mathrm{LOI}_{550}\right)$ was determined and calculated according to Heiri, Lotter, and Lemcke (2001). The dry sieving technique was used to determine the contribution of very coarse sand (1000-2000 $\mu \mathrm{m})$, coarse sand $(500-1000 \mu \mathrm{m})$, medium coarse sand $(250-500 \mu \mathrm{m})$, fine sand $(125-250 \mu \mathrm{m})$, very fine sand $(63-125 \mu \mathrm{m})$, and mud $(<63 \mu \mathrm{m})$ grain size fractions. The method of Folk (1968) was used to quantify the sorting characteristics of sediments. Grain size of sediments was recorded using the standard phi unit $(\phi)$. A cumulative frequency plot of grain size $(\phi)$ was used to measure the mean $\left(M_{z}\right)$ and sorting characteristic $\left(\sigma_{I}\right)$ graphically given by 


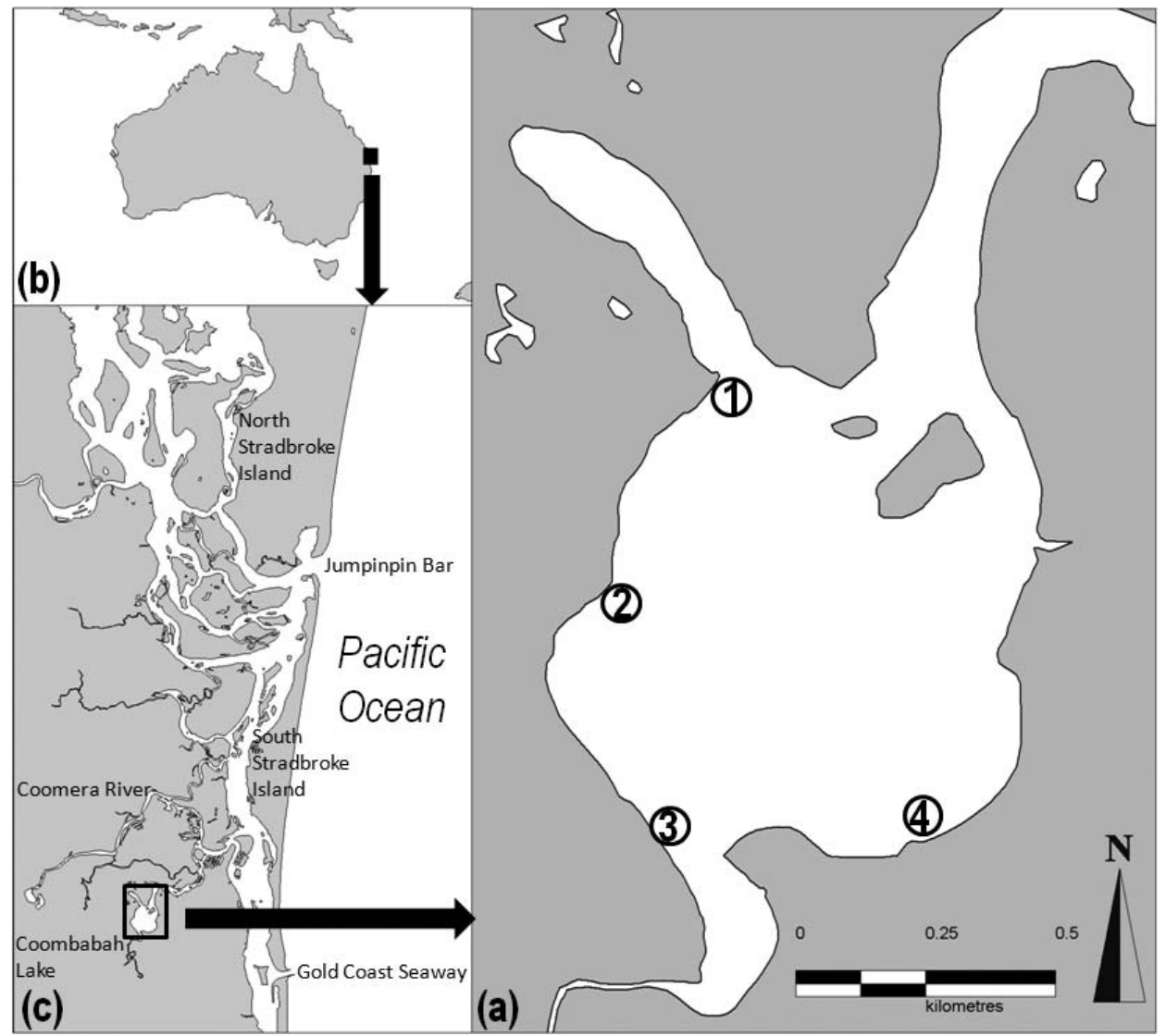

Figure 1. Location of sampling sites within Coombabah Lake (a). Insert shows location of the study area in Australia (b) and southern Moreton Bay (c).

$$
\begin{aligned}
M_{z} & =\frac{(\phi 16+\phi 50+\phi 84)}{3} \\
\sigma_{I} & =\frac{(\phi 84-\phi 16)}{4}+\frac{(\phi 95-\phi 5)}{6.6},
\end{aligned}
$$

where $M_{z}$ is the graphical mean, $\sigma_{I}$ is the sorting value (Inclusive Graphic Standard Deviation), and $\phi_{x}$ is the grain size at the $x \%$ value on the cumulative frequency curve (Folk, 1968).

Descriptive terms of Folk (1968) were used to characterise $M_{z}$ as calculated from Equation 1, including very coarse grained $(-1-0.0 \phi)$, coarse grained (0.0-1.0 $\phi)$, medium grained (1.0-2.0 $\phi)$, fine grained (2.0-3.0 $\phi)$, very fine grained (3.0-4.0 $\phi)$, and coarse silt $(4.0-5.0 \phi)$.

The sorting scale of Folk (1968) is used to characterise the sorting value $\sigma_{I}$ as calculated from Equation 2: very well sorted $\left(\sigma_{I}<0.35\right)$, well sorted $\left(\sigma_{I}=0.35-0.5\right)$, moderately well sorted $\left(\sigma_{I}=0.5-0.7\right)$, moderately sorted $\left(\sigma_{I}=0.7-1.0\right)$, poorly sorted $\left(\sigma_{I}\right.$ $=1.0-2.0)$, very poorly sorted $\left(\sigma_{I}=2.0-4.0\right)$, and extremely poorly sorted $\left(\sigma_{I}>4.0\right)$.

Prior to nutrient analyses all laboratory glass- and plasticware were cleaned by soaking in $10 \%(\mathrm{v} / \mathrm{v}) \mathrm{HCl}(>48 \mathrm{~h})$ then rinsed three times with deionised water (Milli-Q; $18 \mathrm{M} \Omega \mathrm{cm}$ ).
All reagents were of analytical grade purity, and all water used during dilutions was deionised water. Sediment $\mathrm{NH}_{4 \text { bio }}^{+}$and $\mathrm{PO}_{4 \text { bio }}^{3-}$ concentrations were determined by extracting aliquots of the homogenised sediment with $1 \mathrm{M} \mathrm{KCl}$ and $1 \mathrm{M} \mathrm{MgCl}_{2}$, respectively, by shaking. Following extraction, samples were centrifuged and the supernatant filtered (GF/F membrane, 47$\mathrm{mm}$ internal diameter, Millipore) before spectrophotometric analysis at $640 \mathrm{~nm}$ using the phenate method for $\mathrm{NH}_{4 \text { bio }}^{+}$ concentrations and as molybdite reactive phosphorous (690 $\mathrm{nm}$ ) for $\mathrm{PO}_{4 \text { bio }}^{3-}$ concentrations (APHA, 1998).

\section{Benthic Macroinfauna Analyses}

Sediment cores placed in holding tanks were removed and the entire sediment core $(20 \mathrm{~cm}$ internal diameter $\times 30 \mathrm{~cm}$ length) was sieved $(250-\mu \mathrm{m}$ stainless steel mesh) for the collection and identification of benthic macroinfauna species. Evaluation of the depth occurrences of the burrowing macroinfauna showed that more than $90 \%$ of the benthic infauna was concentrated in the top $0-10 \mathrm{~cm}$ interval in all cores sampled. Recovered macroinfauna were rinsed with freshwater to remove any adhering sediment or detritus and were preserved in $70 \%$ ethanol. Specimen identification (species level) and counts were performed under a low powered microscope. Dry weight (biomass ${ }_{\mathrm{DW}}$ ) was determined after drying at $80^{\circ} \mathrm{C}$ for 48 
$\mathrm{h}$ and reported as $\mathrm{g} \mathrm{m}^{-2}$. Shannon diversity index $\left(H^{\prime}\right)$ was calculated according to Lee (1999).

\section{Environmental Data}

Regional air temperature $\left({ }^{\circ} \mathrm{C}\right)$ and rainfall $(\mathrm{mm})$ data obtained from the Australian Bureau of Meteorology automated Gold Coast weather station (Gold Coast Seaway, station number: 040764) were used as a complementary environmental characterisation of the study area. Previous hydrological measurements within the lake (data not shown) indicate that the approximate duration of sediment exposure per tidal cycle at Sites 1, 2, 3, and 4 was approximately 4, 3, 3, and 2 hours, respectively.

\section{Statistical Analyses}

Sediment parameter values for each sample depth horizon across the $15-\mathrm{cm}$ depth profile are reported as mean values \pm standard deviation (SD) from the triplicate cores for each site during each seasonal sampling event. Spatial and temporal variations (between site and/or season) were assessed using analysis of variance (ANOVAs), including Tukey's HSD or Games-Howell post hoc analysis. Prior to the analysis, the homogeneity of variance was evaluated using the Levene test, and, when violated, nonparametric analyses were performed. Pearson correlations (two-tailed; $\alpha=0.05$ ) were used to assess and identify relationships between physicochemical sediment conditions between sites, physicochemical sediment conditions (sample depth: 0-15 cm), environmental parameters, and benthic macroinfauna communities sampled (sample depth: 0-30 cm). Analyses were performed using SPSS Windows (SPSS, Inc., version 11.5.0). The infaunal assemblages and sediment characteristics at the sample sites were analysed using the PRIMER software package from the Plymouth Marine Laboratory (Clarke and Warwick, 2001).

\section{RESULTS
Physicochemical Sediment Parameters}

Daily temperature and rainfall data for the sampled period is shown in Figure 2. During the seasonal sampling events, regional temperatures ranged from $8^{\circ} \mathrm{C}$ (August) to $34.5^{\circ} \mathrm{C}$ (January). The maximum monthly rainfall occurred during November 2006 (122 mm).

No significant seasonal differences were observed at any site for all physical sediment parameters. Annual mean values of the sediment parameters with depth at each sampling site are shown in Table 1. Mean sediment wet-bulk densities ranged between $1.5 \pm 0.1$ (Site 4) to $2.0 \pm 0.1 \mathrm{~g} \mathrm{~cm}^{-3}$ (Site 1) but were relatively consistent at each site with increasing depth. No significant difference was observed between sites. Water content throughout the sampled sediment profiles at all sites ranged from 20.4 to $69.6 \%$ and generally decreased with increasing sediment depth (Table 1). Water content significantly differed between all sample sites $(p<0.001, \alpha=0.05)$, with the exception of Site 2 compared to Site 3.

Mean grain size and sorting of sediments are presented in Table 1 . The mean grain size ranged between very fine grained (Site 4, 0-1 cm and 1-2 cm depths) and coarse grained (Site 2, 10-15 cm depth). Northern sediments located toward the marine entrance of the lake (Sites 1 and 2) were typically described as fine- to medium-grained to moderately to poorly

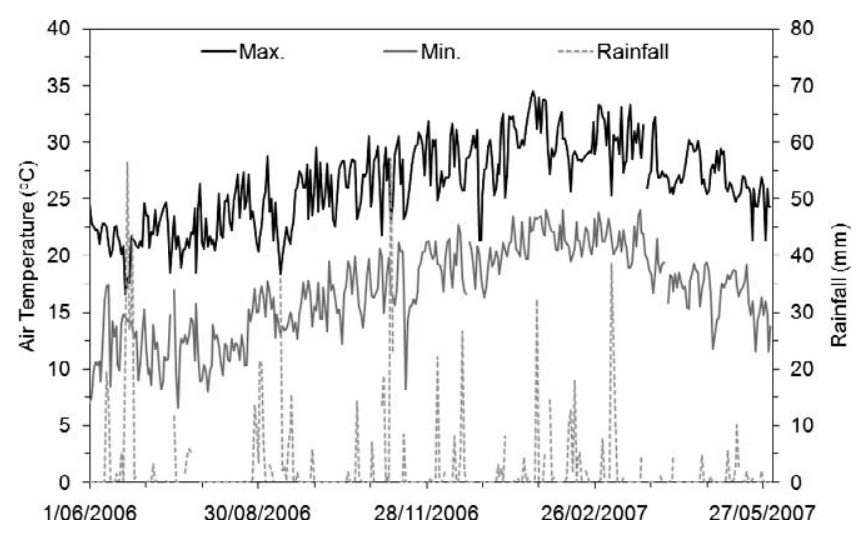

Figure 2. Daily recordings of air temperature (minimum and maximum) and rainfall in the southern Moreton Bay region (Australian Bureau of Meteorology weather station, Gold Coast Seaway, station number: 040764).

sorted sediments. In comparison, the southern sample sites are typically described as fine-grained to well to moderately well sorted. Sediment at the northern Sites 1 and 2 was significantly different in mean grain size compared to the southern Sites 3 and 4. For example, mean grain sizes throughout the sample profiles at Site 1 were significantly greater than Site 4 ( $p=$ $0.002, \alpha=0.05)$, and Site 2 was significantly greater than Site 3 $(p=0.004, \alpha=0.05)$ and Site $4(p=0.002, \alpha=0.05)$. At a depth of $\sim 10 \mathrm{~cm}$, a patchy horizon of mollusc shells was present in the sediments at Sites 1 and 2 .

Lake sediments were characterised by high organic matter contents with mean $\mathrm{LOI}_{550}$ values ranging from $1.21 \pm 0.45 \%$ (Site 1, 1-2 cm depth, summer) to $9.57 \pm 6.53 \%$ (Site $3,10-15$ cm depth, winter) (Figure 3 ). $\mathrm{LOI}_{550}$ values within the southern sites (3 and 4) were greater than the northern sites (1 and 2). Specifically, $\mathrm{LOI}_{550}$ values at Site 3 was significantly greater than Sites $1(p<0.001, \alpha=0.05)$ and $2(p=0.001, \alpha=0.05)$ values. Additionally Site 4 values were significantly greater then Site $1(p<0.001, \alpha=0.05)$ and Site $2(p=0.003, \alpha=0.05)$ values. Maximum $\mathrm{LOI}_{550}$ contents within Site 3 and 4 sediments occurred during winter and within Site 1 and 2 sediments during autumn and spring, respectively.

$\mathrm{PO}_{4 \text { bio }}^{3-}$ concentrations ranged between $1.8 \pm 0.4$ to $21.0 \pm 8.1$ nmol g ${ }^{-1}$ dry wt (Figure 4) and showed no significant difference between sample sites. Furthermore, no significant seasonal differences were observed. Additionally, $\mathrm{NH}_{4 \text { bio }}^{+}$concentrations ranged from $13.2 \pm 3.6$ to $524.0 \pm 26.0 \mathrm{nmol} \mathrm{g}^{-1}$ dry wt (Figure $5)$ and significantly changed between sites and seasons $(p<$ $0.001, \alpha=0.05$ ) during the study. Site 4 concentrations were significantly greater than Site $1(p<0.001, \alpha=0.05)$ and Site 2 $(p=0.001, \alpha=0.05)$, respectively. Maximal $\mathrm{NH}_{4 \text { bio }}^{+}$concentrations at all sites throughout the lake occurred during the summer and autumn sampling periods.

\section{Macroinfauna Dynamics}

Over the course of the sampling programme, 1029 macroinfauna individuals were collected and identified, including six species from three orders representing deposit-feeding and filter-feeding macroinfaunal groups. Macrofauna abun- 
Table 1. Annual averaged depth profiles of sediment parameters at each site (mean values \pm standard deviation; $\mathrm{n}=12$ [three replicates $\times$ four seasons]).

\begin{tabular}{|c|c|c|c|c|c|c|c|}
\hline \multirow[b]{2}{*}{ Site } & \multirow[b]{2}{*}{ Depth $(\mathrm{cm})$} & \multirow[b]{2}{*}{ Wet-Bulk Density $\left(\mathrm{g} \mathrm{cm}^{-3}\right.$ ) } & \multirow[b]{2}{*}{ Water Content $(\%)$} & \multicolumn{2}{|c|}{ Graphic Mean Grain Size } & \multicolumn{2}{|c|}{ Inclusive Graphic Standard Deviation } \\
\hline & & & & $\phi$ & Description & $\sigma_{1}$ & Sorting \\
\hline \multirow[t]{6}{*}{1} & $0-1$ & $1.9 \pm 0.1$ & $27.4 \pm 4.8$ & 2.7 & Fine grained & 0.91 & Moderately sorted \\
\hline & $1-2$ & $1.9 \pm 0.1$ & $23.7 \pm 1.8$ & 2.7 & Fine grained & 0.94 & Moderately sorted \\
\hline & $2-4$ & $1.9 \pm 0.1$ & $22.8 \pm 1.7$ & 2.6 & Fine grained & 0.85 & Moderately sorted \\
\hline & $4-6$ & $2.0 \pm 0.1$ & $23.7 \pm 1.9$ & 2.6 & Fine grained & 0.89 & Moderately sorted \\
\hline & $6-10$ & $2.0 \pm 0.1$ & $23.6 \pm 2.0$ & 2.6 & Fine grained & 0.92 & Moderately sorted \\
\hline & $10-15$ & $2.0 \pm 0.1$ & $24.9 \pm 2.5$ & 2.4 & Fine grained & 0.72 & Moderately sorted \\
\hline \multirow[t]{6}{*}{2} & $0-1$ & $1.6 \pm 0.2$ & $47.3 \pm 13.3$ & 2.0 & Medium grained & 1.45 & Poorly sorted \\
\hline & $1-2$ & $1.6 \pm 0.3$ & $42.7 \pm 12.7$ & 1.6 & Medium grained & 1.61 & Poorly sorted \\
\hline & $2-4$ & $1.6 \pm 0.2$ & $40.7 \pm 10.7$ & 1.2 & Medium grained & 1.81 & Poorly sorted \\
\hline & $4-6$ & $1.7 \pm 0.2$ & $37.6 \pm 9.1$ & 1.3 & Medium grained & 1.91 & Poorly sorted \\
\hline & $6-10$ & $1.8 \pm 0.2$ & $33.0 \pm 7.3$ & 1.1 & Medium grained & 2.03 & Very poorly sorted \\
\hline & $10-15$ & $1.8 \pm 0.2$ & $33.8 \pm 7.3$ & 0.4 & Coarse grained & 1.81 & Poorly sorted \\
\hline \multirow[t]{6}{*}{3} & $0-1$ & $1.6 \pm 0.1$ & $45.8 \pm 4.13$ & 2.9 & Fine grained & 0.83 & Moderately well sorted \\
\hline & $1-2$ & $1.6 \pm 0.1$ & $43.4 \pm 5.6$ & 2.8 & Fine grained & 0.86 & Moderately well sorted \\
\hline & $2-4$ & $1.6 \pm 0.1$ & $41.7 \pm 5.4$ & 2.6 & Fine grained & 0.83 & Moderately well sorted \\
\hline & $4-6$ & $1.7 \pm 0.1$ & $38.6 \pm 2.9$ & 2.6 & Fine grained & 0.89 & Moderately well sorted \\
\hline & $6-10$ & $1.7 \pm 0.1$ & $39.1 \pm 2.2$ & 2.6 & Fine grained & 0.93 & Moderately well sorted \\
\hline & $10-15$ & $1.7 \pm 0.1$ & $40.3 \pm 6.9$ & 2.5 & Fine grained & 0.90 & Moderately well sorted \\
\hline \multirow[t]{6}{*}{4} & $0-1$ & $1.4 \pm 0.1$ & $59.5 \pm 6.3$ & 3.0 & Very fine grained & 0.69 & Well sorted \\
\hline & $1-2$ & $1.5 \pm 0.1$ & $55.2 \pm 5.2$ & 3.0 & Very fine grained & 0.77 & Moderately sorted \\
\hline & $2-4$ & $1.5 \pm 0.1$ & $53.6 \pm 4.0$ & 2.8 & Fine grained & 0.66 & Well sorted \\
\hline & $4-6$ & $1.5 \pm 0.1$ & $52.3 \pm 3.8$ & 2.8 & Fine grained & 0.71 & Well sorted \\
\hline & $6-10$ & $1.5 \pm 0.1$ & $48.6 \pm 3.9$ & 2.9 & Fine grained & 0.80 & Moderately sorted \\
\hline & $10-15$ & $1.6 \pm 0.1$ & $43.2 \pm 3.1$ & 2.9 & Fine grained & 0.75 & Moderately sorted \\
\hline
\end{tabular}

dance demonstrated significant spatial and temporal variations with the greatest combined seasonal abundances reported at the fine-grained Site 4 ( $p<0.001, \alpha=0.05)$ and the greatest abundances across the lake recorded during winter $(<0.001, \alpha=0.05)$. Seasonal trends in total site densities were observed at each of the four sites with temporal changes in macroinfauna densities characterised by a trending decline from winter through to autumn (Figure 6 ). The combined mean site densities were significantly correlated (negatively) with seasonal maximum monthly temperatures $(r=-0.625, p=0.010, n=16)$. Mean combined densities ranged between $74.3 \pm 74.5$ ind. $\mathrm{m}^{-2}$ (Site 1, spring) and $955.5 \pm 624.8$ ind. $\mathrm{m}^{-2}$ (Site 4, winter; Figure 6). Victoriopisa australiensis (amphipods) followed by Simplisetia aequisetis (polychaete worms) were the most numerically dominant species collected (Figure 6). S. aequisetis was the greatest contributor to the burrowing faunal assemblages at Sites 1, 2, and 3, accounting for $60 \%, 87 \%$, and $64 \%$ of the total individuals collected, respectively (Figure 6). V. australiensis accounted for $92 \%$ of all the total collected burrowing macrofauna at Site 4 . The contribution of $V$. australiensis to mean densities decreased from the southern fine grained sites (Sites 3 and 4) in comparison to the northern fine to medium grained sites (Sites 1 and 2). Overall, V. australiensis represents $49 \%$ of the total retrieved macroinfauna across the four sites and four seasons sampled. No single species was recorded simultaneously at all four sites during any of seasonal sampling periods; however, $V$. australiensis, $S$. aequisetis, and $H$. cordiformis were recorded at all four sites during one or more seasons (Table 2). $S$. aequisetis demonstrated a seasonal pattern, with increased densities typically occurring during winter and spring.
Mean site biomass $\mathrm{DW}_{\mathrm{DW}}$ ranged between $0.16 \pm 0.15 \mathrm{~g} \mathrm{~m}^{-2}$ (Site 1 , summer) and $10.44 \pm 11.69$ (Site 1, winter; Figure 6). Combined biomass ${ }_{\mathrm{DW}}$ at Sites 1 and 2 were $91.5 \mathrm{~g} \mathrm{~m}^{-2}$ and 89.0 $\mathrm{g} \mathrm{m}^{-2}$, respectively, compared to $18.0 \mathrm{~g} \mathrm{~m}^{-2}$ and $32.6 \mathrm{~g} \mathrm{~m}^{-2}$ for Sites 3 and 4, respectively. V. australiensis contributed

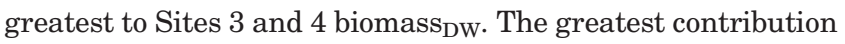
to biomass ${ }_{\mathrm{DW}}$ by $S$. aequisetis occurred at Site $3(50 \%)$. Representing just $20 \%$ and $3 \%$ of the mean biomass at Sites 1 and 2, H. Cordiformis accounted for $61 \%$ and $82 \%$ of the recorded biomass $\mathrm{DW}_{\mathrm{DW}}$ at these sites, respectively.

Site 1 demonstrated the greatest seasonal Shannon diversity index values with increased values during winter (1.82) and autumn (1.74). Seasonal lake-wide diversity values ranged between 1.12 (spring) and 1.48 (autumn) with an annual mean value of $1.3 \pm 0.16$

\section{Relationships between Sediment Parameters and Macroinfauna Dynamics}

Correlations between depth-averaged physicochemical sediment parameters are shown in Table 3. Significant correlations were observed between sediment parameters and macroinfauna mean density and biomass ${ }_{\mathrm{DW}}$. The combined density of macroinfauna was significantly correlated with seasonal depth-averaged sediment density $(r=-0.636, p=0.008, n=16)$, porosity $(r=0.570, p=0.21, n=16)$, and organic matter content $\left(\mathrm{LOI}_{550} ; r=0.755, p=0.001, n=16\right)$. Mean densities of $V$. australiensis significantly correlated with mean $\mathrm{NH}_{4 \text { bio }}^{+}(0-4$ $\mathrm{cm} ; r=0.505, p=0.046, n=16)$, mean $\mathrm{PO}_{4 \text { bio }}^{3-}(r=0.714, p=$ $0.002, n=16)$, and $\mathrm{LOI}_{550}(r=0.682, p=0.004, n=16)$. Additionally, mean density $S$. Aequisetis also significantly correlated with $\mathrm{NH}_{4 \text { bio }}^{+}(0-4 \mathrm{~cm} ; r=-0.499, p=0.049, n=16)$ (Table 4). Furthermore, V. australiensis biomass $\mathrm{Dw}_{\mathrm{w}}$ significantly correlated $\mathrm{NH}_{4 \text { bio }}^{+}(0-4 \mathrm{~cm} ; r=-0.508, p=0.045, n=16)$, 


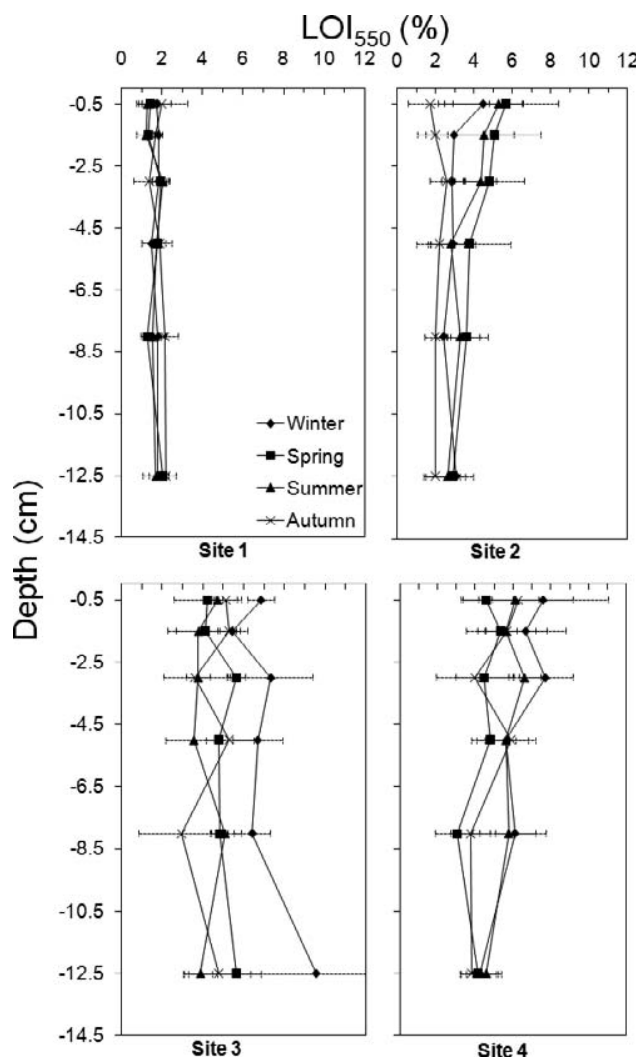

Figure 3. Seasonal depth profiles of sediment $\mathrm{LOI}_{550}$ contents at each sampling site within Coombabah Lake. Data are mean values, and error bars show the standard deviation of the mean rate $(n=3)$.

mean $\mathrm{PO}_{4 \text { bio }}^{3-}(r=0.684, p=0.003, n=16)$, and $\mathrm{LOI}_{550}(r=0.552$, $p=0.027, n=16$ ). Mean biomass $\mathrm{Dw}_{\mathrm{w}}$ of $H$. cordiformis also significantly correlated with $\mathrm{LOI}_{550}$ values $(r=-0.505, p=$ $0.046, n=16$, Table 4).

\section{DISCUSSION}

The northern sample sites (Sites 1 and 2) were characterised by fine to medium grained to moderately to poorly sorted sediments and the southern sample sites (Sites 3 and 4) by fine grained to moderately well to well-sorted sediments, as a result of the hydrodynamic regime and settling behaviour of sediment particles (Dronkers, 1986; van Leussen, 1999). The tidal regime of the lake and Coombabah Creek indicates pumping of sanddominated sediments from the downstream marine entrance landward into the northern areas of the lake (Ali, Zhang, and Lemckert, 2009; Dunn et al., 2007a).

Nutrient concentrations measured during this study were comparable to surface sediment concentrations measured previously within the lake (Dunn et al., 2007b). Spatial and temporal differences in sedimentary inorganic nutrient concentrations throughout the lake are attributable to variations in sediment grain size, organic matter remineralisation, and external nutrient inputs. Sediment organic matter contents

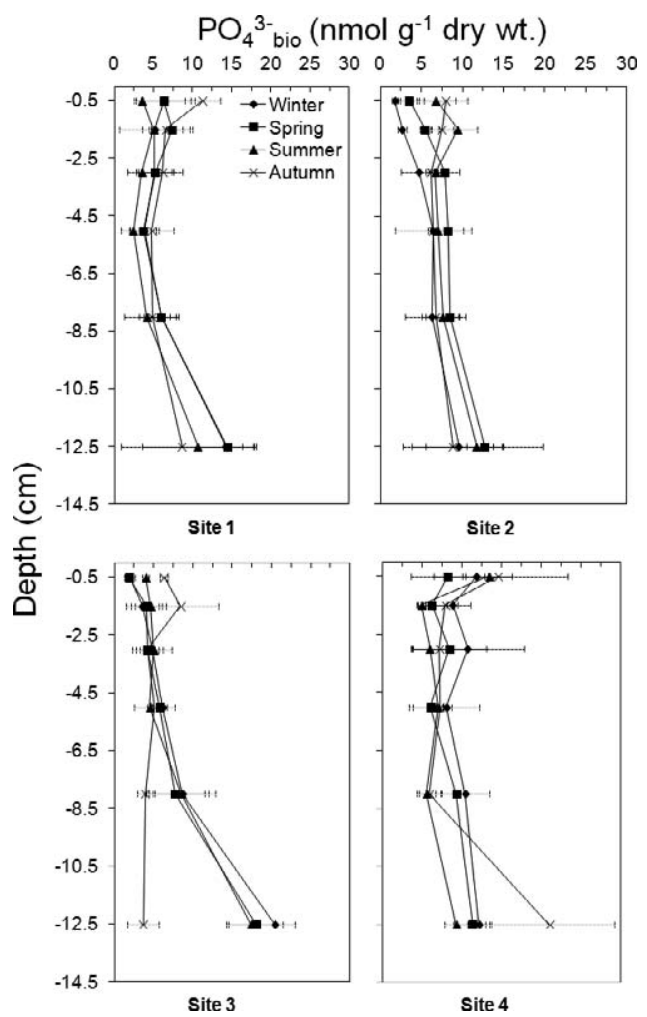

Figure 4. Seasonal depth profiles of sediment $\mathrm{PO}_{4 \text { bio }}^{3-}$ concentrations at each sampling site. Data are mean values, and error bars show the standard deviation of the mean rate $(n=3)$

were greater within the southern lake fine-grained to moderately well to well-sorted sediments compared to the northern fine to medium grained to moderately to poorly sorted sediments. Organic matter content within the lake corresponded to the well-established and commonly observed correlation of increased organic matter with reducing sediment grain size (e.g., Dankers and Beukema, 1983; Dunn et al., 2008; Schrijvers, Van Gansbeke, and Vincx, 1995).

During a previous stable isotope and lipid biomarker study, Dunn et al. (2008) identified a greater contribution of autochthonous and labile organic matter to the sedimentary organic matter pool in the northern (marine entrance) sediments compared to the more allochthonous sourced organic matter of the southern region of the lake. Dunn et al. (2008) also observed that lower $\mathrm{C} / \mathrm{N}$ ratios within the lake corresponded to regions of increased concentrations of chlorophyll- $a$ and phaeopigment concentrations, with significant negative correlations occurring between chlorophyll- $a$ and phaeopigment concentrations and $\mathrm{C} / \mathrm{N}$ ratios, reflecting the influence of the low $\mathrm{C} / \mathrm{N}$ ratio microalgal biomass and bacterial communities. In addition to stimulating microbial metabolism, sediment oxygen demand and nutrient regeneration (Ferguson, Eyre, and Gay, 2003; Slomp et al., 1993), sedimentary organic matter is a major food source for benthic infauna (Cheng and Chang, 1999; Spilmont et al., 2009) despite its often refractory nature 


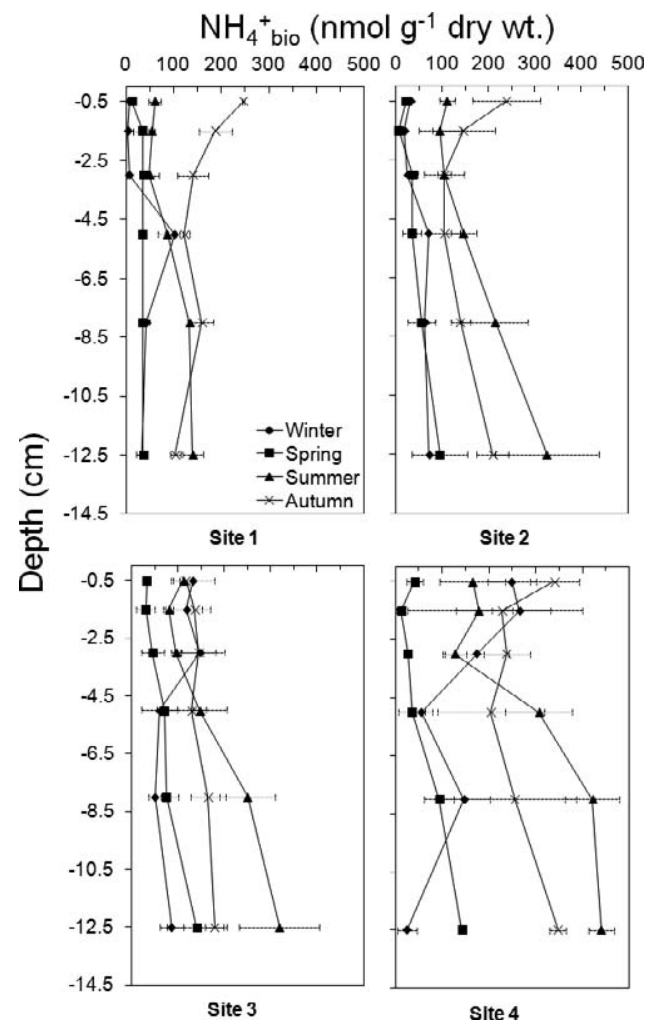

Figure 5. Seasonal depth profiles of sediment $\mathrm{NH}_{4 \text { bio }}^{+}$concentrations at each sampling site. Data are mean values, and error bars show the standard deviation of the mean rate $(n=3)$.
(Cheng, 1995). Variations in the delivery and bioavailability of organic matter and regenerated nutrients, therefore, might influence benthic infauna population dynamics (Cheng and Chang, 1999; Ponti, Casselli, and Abbiati, 2010; SánchezMoyano, García-Asencio, and García-Gómez, 2010). During this study, increases in the combined macroinfauna density were observed to significantly correlate $(r=0.755, p=0.001, n=$ 16) with increased sediment organic matter content (food supply) within the surface sediments of Coombabah Lake, indicating that sediment column organic matter content was a factor influencing the combined macrofauna population dynamics of Coombabah Lake on a relatively small spatial scale (e.g., $\sim 500 \mathrm{~m}$ ). The significant correlation was influenced by the increased contribution of $V$. australiensis to overall densities in the fine-grained southern sites characterised by increased contents of organic matter. Additionally, significant correlations between $V$. australiensis density and mean $\mathrm{NH}_{4}^{+}$bio and $\mathrm{PO}_{4 \text { bio }}^{3-}$ concentrations were also identified (Table 4). The findings of the study illustrate associations between $V$. australiensis densities, $\mathrm{LOI}_{550}, \mathrm{NH}_{4 \text { bio }}^{+}$, and $\mathrm{PO}_{4 \text { bio }}^{3-}$ concentrations within Coombabah Lake, which themselves share significant correlations (Table 3). Additionally, significant correlations were also observed between $\mathrm{LOI}_{550}$ content and mean biomass DW $\left._{\text {of } V \text {.australiensis }(~} r=0.552, p=0.027, n=16\right)$, again reflecting the importance of organic matter content-food supply to the deposit feeding species. Previously several studies have also established sediment characteristics as significant factors influencing the distribution of macroinfauna species in estuarine and coastal waters (e.g., Cheng and Chang, 1999; Kanaya and Kikuchi, 2008; Ysebaert et al., 2002, 2003).

Although the sample sites were paucispecific, the lake included species commonly observed in intertidal surface sediments along the coastline of eastern Australia (e.g., Hirst, 2004; Ruello, 1975). Recorded densities are similar to those previously reported within the intertidal lake and surrounding environments (Dunn et al., 2009; GHD, 2003) and those reported in other shallow intertidal sediments (Kanaya and
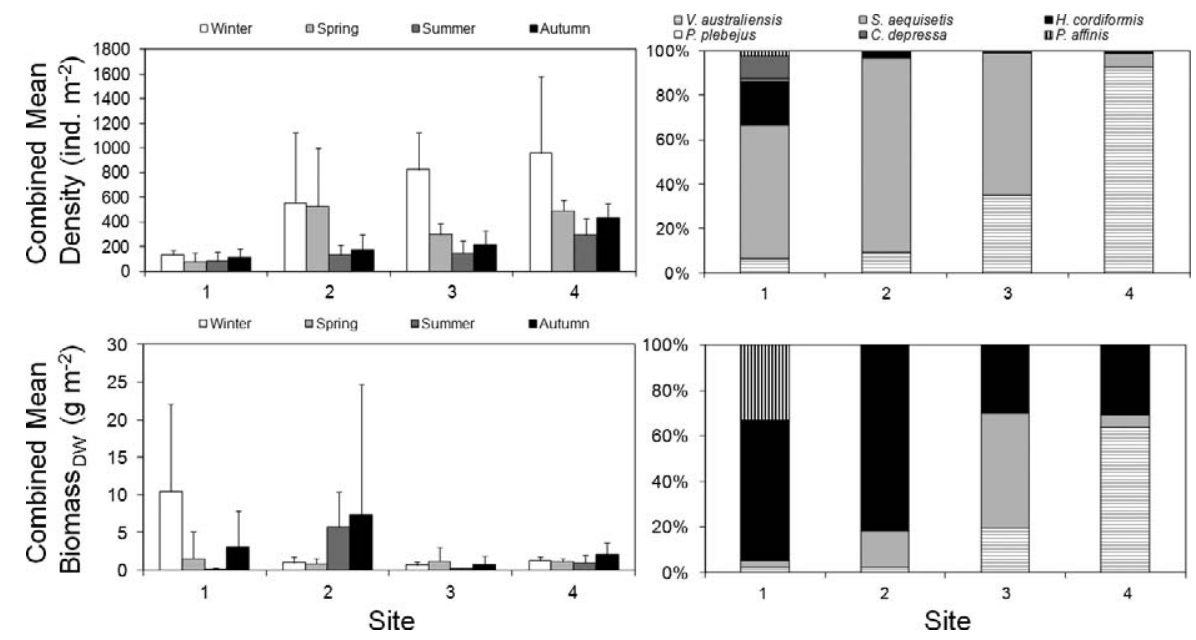

Figure 6. Burrowing macroinfaunal dynamics, including (a) mean density, (b) species contributions to mean density, (c) total biomass $\mathrm{Dw}$, and (d) species contribution to total biomass ${ }_{\mathrm{DW}}$. 
Table 2. Density (ind. $\mathrm{m}^{-2}$ ) and biomass ${ }_{D W}\left(\mathrm{~g} \mathrm{~m}^{-2}\right)$ of Coombabah Lake macroinfauna species (mean values \pm standard deviation or single recorded density where $\mathrm{n}=1$ ).

\begin{tabular}{|c|c|c|c|c|c|c|c|}
\hline \multirow[b]{3}{*}{ Site } & \multirow[b]{3}{*}{ Season $^{a}$} & \multicolumn{6}{|c|}{ Species (Family) } \\
\hline & & \multicolumn{5}{|c|}{ Deposit Feeder } & \multirow{2}{*}{$\begin{array}{c}\text { Filter Feeder } \\
\text { Pitar affinis } \\
\text { (Veneridae) }\end{array}$} \\
\hline & & $\begin{array}{c}\text { Victoriopisa australiensis } \\
\text { (Melitidae) }\end{array}$ & $\begin{array}{c}\text { Simplisetia aequisetis } \\
\text { (Nereididae) }\end{array}$ & $\begin{array}{l}\text { Heloecius cordiformis } \\
\text { (Ocypodidae) }\end{array}$ & $\begin{array}{l}\text { Penaeus plebejus } \\
\text { (Penaeidae) }\end{array}$ & $\begin{array}{l}\text { Clorida depressa } \\
\quad \text { (Squillidae) }\end{array}$ & \\
\hline \multicolumn{8}{|c|}{ Density (ind. $\mathrm{m}^{-2}$ ) } \\
\hline 1 & $\mathrm{~W}$ & $79.6 \pm 22.5$ & $95.6 \pm 31.9$ & $57.3 \pm 14.2$ & - & - & $31.85 \pm 0.0$ \\
\hline 1 & $\mathrm{Sp}$ & 63.7 & $159.3 \pm 45.0$ & 63.7 & - & 31.9 & - \\
\hline 1 & $\mathrm{Su}$ & - & $106.2 \pm 71.7$ & - & - & - & - \\
\hline 1 & $\mathrm{~A}$ & - & 47.8 & $53.0 \pm 18.4$ & 31.9 & 31.9 & - \\
\hline 2 & $\mathrm{~W}$ & $76.4 \pm 48.3$ & $503.2 \pm 615.4$ & 31.9 & - & - & - \\
\hline 2 & $\mathrm{Sp}$ & $79.3 \pm 22.5$ & $498.9 \pm 477.9$ & - & - & - & - \\
\hline 2 & $\mathrm{Su}$ & $47.8 \pm 22.5$ & $108.9 \pm 62.1$ & $39.8 \pm 15.9$ & - & - & - \\
\hline 2 & $\mathrm{~A}$ & $42.5 \pm 18.4$ & $159.3 \pm 140.0$ & 63.7 & 31.9 & - & - \\
\hline 3 & W & $339.7 \pm 109.7$ & $472.4 \pm 299.7$ & $31.9 \pm 0.0$ & - & - & - \\
\hline 3 & $\mathrm{Sp}$ & $119.4 \pm 18.4$ & $210.2 \pm 26.0$ & 31.9 & - & - & - \\
\hline 3 & $\mathrm{Su}$ & $63.7 \pm 45.0$ & $146.5 \pm 73.3$ & - & - & - & - \\
\hline 3 & $\mathrm{~A}$ & $66.3 \pm 66.3$ & $172.0 \pm 102.2$ & - & - & - & - \\
\hline 4 & $\mathrm{~W}$ & $897.1 \pm 560.2$ & $42.5 \pm 75.8$ & 31.9 & - & - & - \\
\hline 4 & $\mathrm{Sp}$ & $440.6 \pm 68.1$ & $71.7 \pm 18.4$ & - & - & - & - \\
\hline 4 & $\mathrm{Su}$ & $254.8 \pm 146.6$ & 127.4 & $31.9 \pm 0.0$ & - & - & - \\
\hline 4 & A & $414.0 \pm 122.5$ & 31.9 & $31.9 \pm 0.0$ & - & - & - \\
\hline \multicolumn{8}{|c|}{$\operatorname{Biomass}_{\mathrm{DW}}\left(\mathrm{g} \mathrm{m}^{-2}\right)$} \\
\hline 1 & $\mathrm{~W}$ & $0.87 \pm 1.21$ & $0.47 \pm 0.60$ & $5.81 \pm 4.68$ & - & - & $15.22 \pm 8.70$ \\
\hline 1 & $\mathrm{Sp}$ & 0.81 & $0.18 \pm 0.11$ & 8.21 & - & 0.05 & - \\
\hline 1 & $\mathrm{Su}$ & - & $0.14 \pm 0.15$ & - & - & - & - \\
\hline 1 & $\mathrm{~A}$ & - & 0.09 & $4.96 \pm 4.25$ & 0.08 & 0.02 & - \\
\hline 2 & W & $0.27 \pm 0.34$ & $0.58 \pm 0.42$ & 0.51 & - & - & - \\
\hline 2 & $\mathrm{Sp}$ & $0.11 \pm 0.12$ & $0.81 \pm 0.70$ & - & - & - & - \\
\hline 2 & $\mathrm{Su}$ & $0.06 \pm 0.03$ & $0.73 \pm 1.36$ & $7.41 \pm 4.49$ & - & - & - \\
\hline 2 & A & $0.09 \pm 0.05$ & $0.27 \pm 0.26$ & 42.7 & 0.07 & - & - \\
\hline 3 & W & $0.35 \pm 0.14$ & $0.44 \pm 0.31$ & $0.29 \pm 0.38$ & - & - & - \\
\hline 3 & $\mathrm{Sp}$ & $0.15 \pm 0.11$ & $0.28 \pm 0.17$ & 4.87 & - & - & - \\
\hline 3 & $\mathrm{Su}$ & $0.07 \pm 0.04$ & $0.17 \pm 0.10$ & - & - & - & - \\
\hline 3 & A & $0.16 \pm 0.05$ & $0.77 \pm 1.32$ & - & - & - & - \\
\hline 4 & W & $1.14 \pm 0.53$ & $0.07 \pm 0.03$ & 0.62 & - & - & - \\
\hline 4 & $\mathrm{Sp}$ & $1.03 \pm 0.27$ & $0.16 \pm 0.10$ & - & - & - & - \\
\hline 4 & $\mathrm{Su}$ & $0.49 \pm 0.41$ & 0.44 & $0.95 \pm 1.02$ & - & - & - \\
\hline 4 & A & $0.78 \pm 0.28$ & 0.10 & $2.50 \pm 0.82$ & - & - & - \\
\hline
\end{tabular}

${ }^{\mathrm{a}} \mathrm{W}, \mathrm{Sp}, \mathrm{Su}$, and $\mathrm{A}$ represents winter, spring, summer, and autumn, respectively

Table 3. Pearson correlation coefficients between mean annual sediment parameter values for each sediment depth horizon $(\mathrm{n}=24$ [six sample horizons $\times$ four seasons]).

\begin{tabular}{|c|c|c|c|c|c|c|}
\hline & Water content $(\%)$ & $<63 \mu \mathrm{m}(\%)$ & $>250 \mu \mathrm{m}$ & $\mathrm{LOI}_{550}(\%)$ & $\mathrm{NH}_{4 \text { bio }}^{+}$(nmol g ${ }^{-1}$ dry wt.) & $\mathrm{PO}_{4 \text { bio }}^{3-}\left(\right.$ nmol g ${ }^{-1}$ dry wt. $)$ \\
\hline \multicolumn{7}{|c|}{ Wet-bulk density } \\
\hline$r$ & $-0.995^{* *}$ & -0.205 & $-0.442^{*}$ & $-0.921 * *$ & $-0.554^{* *}$ & -0.161 \\
\hline$p$ & 0.000 & 0.337 & 0.030 & 0.000 & 0.005 & 0.453 \\
\hline \multicolumn{7}{|c|}{ Water content } \\
\hline$r$ & & 0.226 & $-0.446 *$ & $0.905^{* *}$ & $0.586 * *$ & 0.188 \\
\hline$p$ & & 0.287 & 0.029 & 0.000 & 0.003 & 0.379 \\
\hline \multicolumn{7}{|c|}{$<63 \mu \mathrm{m}$} \\
\hline$r$ & & & $-0.713^{* *}$ & 0.225 & 0.361 & -0.057 \\
\hline$p$ & & & 0.000 & 0.290 & 0.083 & 0.792 \\
\hline \multicolumn{7}{|c|}{$>250 \mu \mathrm{m}$} \\
\hline$r$ & & & & $0.458^{*}$ & -0.403 & -0.036 \\
\hline$p$ & & & & 0.024 & 0.051 & 0.868 \\
\hline \multicolumn{7}{|c|}{$\mathrm{LOI}_{550}$} \\
\hline$r$ & & & & & $0.573 * *$ & 0.224 \\
\hline$p$ & & & & & 0.003 & 0.292 \\
\hline \multicolumn{7}{|c|}{$\mathrm{NH}_{4 \text { bio }}^{+}$} \\
\hline$r$ & & & & & & $0.637 * *$ \\
\hline$p$ & & & & & & 0.001 \\
\hline
\end{tabular}

* Correlation significant at the 0.05 level [two-tailed].

** Correlation significant at the 0.01 level [two-tailed]. 
Table 4. Species-specific Pearson correlation coefficients between mean density and depth-averaged (0-4 cm and 0-15 cm) mean sediment nutrient concentrations and mean $\mathrm{LOI}_{550}$ content and biomass ${ }_{D W}$ and depth-averaged $(0-4 \mathrm{~cm}$ and $0-15 \mathrm{~cm})$ mean sediment nutrient concentrations and mean $L O I_{550}$ content $(\mathrm{n}=16$ [four sites $\times$ four seasons]).

\begin{tabular}{|c|c|c|c|c|c|}
\hline & $\begin{array}{l}\mathrm{NH}_{4 \text { bio }}^{+}(0-4 \mathrm{~cm}), \\
\text { nmol g }^{-1} \text { dry wt. }\end{array}$ & $\begin{array}{l}\mathrm{NH}_{4 \text { bio }}^{+}(0-15 \mathrm{~cm}) \\
\mathrm{nmol} \mathrm{g}^{-1} \text { dry wt. }\end{array}$ & $\begin{array}{l}\mathrm{PO}_{4 \text { bio }}^{3-}(0-4 \mathrm{~cm}) \\
\text { nmol g } \\
\end{array}$ & $\begin{array}{l}\mathrm{PO}_{4 \text { bio }}^{3-}(0-15 \mathrm{~cm}) \\
\text { nmol g } \\
\end{array}$ & $\begin{array}{c}\mathrm{LOI}_{550}(0-15 \mathrm{~cm}), \\
\%\end{array}$ \\
\hline \multicolumn{6}{|c|}{ Mean density (ind. $\mathrm{m}^{-2}$ ) } \\
\hline \multicolumn{6}{|c|}{ V. australiensis } \\
\hline$r$ & $0.505^{*}$ & 0.282 & 0.322 & $0.714^{* *}$ & $0.682^{* *}$ \\
\hline$p$ & 0.046 & 0.290 & 0.224 & 0.002 & 0.004 \\
\hline \multicolumn{6}{|c|}{ S. aequisetis } \\
\hline$r$ & $-0.499 *$ & -0.451 & -0.245 & -0.311 & 0.243 \\
\hline$p$ & 0.049 & 0.077 & 0.359 & 0.242 & 0.365 \\
\hline \multicolumn{6}{|c|}{ H. cordiformis } \\
\hline$r$ & -0.153 & 0.030 & -0.051 & 0.120 & -0.342 \\
\hline$p$ & 0.571 & 0.912 & 0.852 & 0.659 & 0.195 \\
\hline \multicolumn{6}{|c|}{ P. plebejus } \\
\hline$r$ & 0.113 & 0.184 & -0.061 & 0.470 & 0.427 \\
\hline$p$ & 0.676 & 0.495 & 0.822 & 0.066 & 0.099 \\
\hline \multicolumn{6}{|c|}{ C. depressa } \\
\hline$r$ & 0.109 & -0.132 & -0.079 & 0.080 & 0.478 \\
\hline$p$ & 0.688 & 0.625 & 0.772 & 0.768 & 0.061 \\
\hline \multicolumn{6}{|c|}{ P. affinis } \\
\hline$r$ & 0.109 & -0.132 & 0.080 & -0.079 & -0.478 \\
\hline$p$ & 0.688 & 0.625 & 0.768 & 0.772 & 0.061 \\
\hline \multicolumn{6}{|c|}{ Mean biomass ${ }_{\mathrm{DW}}\left(\mathrm{g} \mathrm{m}^{-2}\right)$} \\
\hline \multicolumn{6}{|c|}{ V. australiensis } \\
\hline$r$ & $0.508^{*}$ & 0.238 & 0.373 & $0.684 * *$ & $0.552^{*}$ \\
\hline$p$ & 0.045 & 0.375 & 0.154 & 0.003 & 0.027 \\
\hline \multicolumn{6}{|c|}{ S. aequisetis } \\
\hline$r$ & -0.482 & -0.250 & -0.263 & -0.327 & 0.146 \\
\hline$p$ & 0.059 & 0.351 & 0.325 & 0.217 & 0.589 \\
\hline \multicolumn{6}{|c|}{ H. cordiformis } \\
\hline$r$ & -0.328 & 0.074 & 0.054 & 0.051 & $-0.505^{*}$ \\
\hline$p$ & 0.215 & 0.786 & 0.844 & 0.852 & 0.046 \\
\hline \multicolumn{6}{|c|}{ P. plebejus } \\
\hline$r$ & 0.059 & 0.182 & 0.440 & -0.057 & 0.421 \\
\hline$p$ & 0.828 & 0.500 & 0.088 & 0.833 & 0.104 \\
\hline \multicolumn{6}{|c|}{ C. depressa } \\
\hline$r$ & 0.166 & 0.448 & 0.494 & -0.064 & 0.426 \\
\hline$p$ & 0.539 & -0.309 & 0.052 & 0.813 & 0.100 \\
\hline \multicolumn{6}{|c|}{ P. affinis } \\
\hline$r$ & -0.323 & -0.309 & 0.494 & -0.106 & 0.328 \\
\hline$p$ & 0.233 & 0.244 & 0.052 & 0.697 & 0.215 \\
\hline
\end{tabular}

* Correlation significant at the 0.05 level (two-tailed)

** Correlation significant at the 0.01 level (two-tailed).

Kikuchi, 2008; Kanaya, Suzuki, and Kikuchi, 2011; Mucha, Vasconcelos, and Bordalo, 2004).

Species present demonstrated temporal variations with low abundance during summer conditions and significantly greater abundance during winter conditions, with mean site densities significantly correlating (negatively) with seasonal maximum monthly temperatures $(r=-0.625, p=0.010, n=16)$. In addition to abundances, seasonal shifts in community structures were also observed. This finding suggests that seasonal temperature variation plays a potentially key role in the overall temporal macrofauna population dynamics of Coombabah Lake. Temporal evolutions observed within the lake have also been reported in temperate (e.g., Ysebaert and Herman, 2002) and subtropical intertidal environments (e.g., Chang, 1995; Da Cunha Lana and Guiss, 1991; Fonseca and Netto, 2006). The temporal variations observed within Coombabah Lake, however, are in contrast to those recorded in some other studies within Australian intertidal systems that reported no significant seasonal trends (Dittman, 2002; Jones, Watson-Russell, and Murray, 1986; Rainer, 1981). In many cases, intra-annual trends in macrofauna dynamics are attributable to patterns of species recruitment, water column and sediment conditions, competition, and predation stresses (Moreira, Aldea, and Troncoso, 2010). These facts could help explain the lower 
values of density observed during summer in Coombabah Lake, with recruitment potentially occurring during autumn, together with an increase in food supply (organic matter) leading to maximum macroinfauna densities during winter. This could be especially true for Site 3 and Site 4 where maximum $\mathrm{LOI}_{550}$ values, representing a food supply, occurred during winter.

Predation is most often presumed to be an important organising force of soft-sediment community structures (Bell, 1980; Brey, 1991). Furthermore, a feature of soft sediments is that any epibenthic predator feeding on the infauna is almost bound to cause a significant disturbance to the substrate (Glassom and Branch, 1997), potentially further influencing infauna dynamics. Macroinfauna within Coombabah Lake provides food sources for commercially and recreationally important fish and migratory wading bird species. Predation pressures presumably include resident species, Sillago ciliate (whiting) and Platycephalus fuscus (dusky flathead), which would typically feed in sandier sediments (northern region), and Acanthopagrus australis (bream) and Mugil cephalus (mullet), which generally feed in more mud-dominated sediments (GHD, 2003). Intertidal regions and sand/mud flats are also important feeding grounds for shorebirds, which are attracted to prey such as infaunal polychaetes and amphipods (Evans et al., 1998). In addition to resident shorebirds, the lake often serves as an important bird-staging area along avian migratory routes as an important declared migratory bird habitat. Migratory wading birds arriving from Europe and Asia during October (spring) to May (autumn) tend to roost in close proximity to surrounding feeding grounds and move out to feed on the tidal flats, often in hundreds (Dunn, personal observation), during ebb tides. Increased predation pressures resulting from the presence of migratory wading birds within the lake coincide with the minimum observed macroinfauna densities within the lake during summer. Avian predation resulting in reduced densities of prey species in intertidal soft-sediment environments has been demonstrated by many studies (e.g., Evans et al., 1998; Hulscher, 1982; Quammen, 1981; Rosa et al., 2008; Zwarts and Blomert, 1992). This observation suggests that avian predation is potentially a key factor influencing the temporal macrofauna population dynamics of Coombabah Lake.

\section{CONCLUSION}

In conclusion, this study investigated physicochemical sediment characteristics and macroinfauna dynamics within the sediments of Coombabah Lake. Seasonal sampling events indicated that physical sediment parameters demonstrated spatial variations but little seasonal variability in comparison to nutrient and organic matter concentrations. Spatial and temporal variations of the deposit-feeding and filter-feeding macroinfauna populations were observed according to sediment condition and sample season. Variations in the physicochemical surface parameters within the subtropical lake provide macroinfauna with different habitats that resulted in the coexistence of infauna with different habitat selectivity within a relatively small scale (e.g., approximately $500 \mathrm{~m}$ ). During the study the highest combined species densities occurred in the southern fine- grained to moderately well to well-sorted sediments (Sites 3 and 4). Variations of mean macroinfauna density and biomass $s_{\mathrm{DW}}$ within the lake significantly correlated to nutrient and organic matter content. Strong temporal trends in total site densities were observed at each of the lake sites with significantly greater abundances and biomass observed during the winter.

The temporal variation of lake macroinfauna observed during this study showed trends that are hypothesised to be related to changing biotic and abiotic factors, including meteorological conditions, organic matter supply, patterns of species recruitment, and predation stresses. Specifically, the presence of migratory wading birds (October to May) within Coombabah Lake coincided with the minimum observed macroinfauna densities. In addition to interannual variations, biotic and abiotic factors would presumably determine long-term (intraannual) variations of macroinfauna assemblages throughout Coombabah Lake.

\section{ACKNOWLEDGMENTS}

The authors thank W. Bennett, D. Dunn, K. Dunn, T. Dunn, M. Jordan, and D. Robertson for fieldwork assistance. The authors would also like to thank Dr. Kylie Pitt for guidance on the application of statistical analyses and comments of the early manuscript drafts.

\section{LITERATURE CITED}

Ali, A.; Lemckert, C.J., and Dunn, R.J.K., 2010. Salt fluxes within a very shallow sub-tropical estuary. Journal of Coastal Research, 26(3), 436-443.

Ali, A.; Zhang, H., and Lemckert, C.J., 2009. Numerical study of the hydrodynamics of a very shallow estuarine system-Coombabah Lake, Gold Coast, Australia. In: da Silva, C.P. (ed.), Proceedings of the 2009 International Coastal Symposium, Portugal. Journal of Coastal Research, Special Issue No. 56, 922-926.

Alongi, D.M., 1998. Coastal Ecosystem Processes. Boca Raton: CRC, $419 p$.

American Public Health Association (APHA), 1998. Part 4000 inorganic nonmetallic constituents. In: Franson, M.A.H. (ed.), Standard Methods for the Examination of Water and Wastewater, 20th edition Washington, DC: American Public Health Association.

Arvanitidis, C.; Koutsoubas, D.; Dounas, C., and Eleftheriou, A., 1999 Annelid fauna of a Mediterranean lagoon (Gialova Lagoon, southwest Greece): community structure in a severely fluctuating environment. Journal of the Marine Biological Association of the $U K, 79(5), 849-856$.

Bell, S.S., 1980. Meiofauna-macrofauna interactions in a high salt marsh habitat. Ecological Monographs, 50(4), 487-505.

Brey, T., 1991. The relative importance of biological and physical disturbance: an example from intertidal and subtidal sandy bottom communities. Estuarine, Coastal and Shelf Science, 33(4), 339-360.

Cheng, I.-J., 1995. The temporal changes in benthic abundances and sediment nutrients in a mudflat of the Chuwei Mangrove Forest, Taiwan. Hydrobiologia, 295(1-3), 221-230.

Cheng, I.-J. and Chang, P.-C., 1999. The relationship between surface macrofauna and sediment nutrients in a mudflat of the Chuwei mangrove forest, Taiwan. Bulletin of Marine Science, 65(14), 603616.

Cifuentes, L.A., 1991. Spatial and temporal variations in terrestriallyderived organic matter from sediments of the Delaware estuary. Estuaries, 14(4), 414-429.

Clarke, K.R. and Warwick, R.M., 2001. PRIMER v5: User manual. Plymouth, UK: PRIMER-E Limited.

Da Cunha Lana, P. and Guiss, C., 1991. Influence of Spartina alterniflora on structure and temporal variability of macrobenthic 
associations in a tidal flat of Paranaguá Bay (southeastern Brazil). Marine Ecology Progress Series, 73, 231-244.

Dankers, N. and Beukema, J.J., 1983. Distributional patterns of macrozoobenthic species in relation to some environmental factors. In: Wolff, W.J. (ed.), Ecology of the Wadden Sea, Vol. 1. Balkema, The Netherlands: Rotterdam, pp. 69-103.

Dittmann, S., 2002. Benthic fauna in tropical tidal flats of Hinchinbrook Channel, NE Australia: diversity, abundance and their spatial and temporal variation. Wetlands Ecology and Management, 10(4), 323-333.

Dronkers, J., 1986. Tidal asymmetry and estuarine morphology. Netherlands Journal of Sea Research, 41, 109-118.

Dunn, R.J.K.; Ali, A.; Lemckert, C.J.; Teasdale, P.R., and Welsh, D.T. 2007a. Short-term variability of physico-chemical parameters and the estimated transport of filterable nutrients and chlorophyll- $a$ in the urbanised Coombabah Lake and Coombabah Creek system, southern Moreton Bay, Australia. In: Lemckert, C.J. (ed.), Proceedings of the 2007 International Coastal Symposium, Australia. Journal of Coastal Research, Special Issue No. 50, 10621068.

Dunn, R.J.K.; Lemckert, C.J.; Teasdale, P.R., and Welsh, D.T., 2007b. Distribution of nutrients in surface and sub-surface sediments of Coombabah Lake, southern Moreton Bay (Australia). Marine Pollution Bulletin, 54(5), 606-614.

Dunn, R.J.K.; Welsh, D.T.; Jordan, M.A.; Arthur, J.M.; Lemckert, C.J., and Teasdale, P.R., 2012. Interactive influences of the marine yabby (Trypaea australiensis) and mangrove (Avicennia marina) leaf litter on benthic metabolism and nitrogen cycling in sandy estuarine sediment. Hydrobiologia, 693(1), 117-129.

Dunn, R.J.K.; Welsh, D.T.; Jordan, M.A.; Teasdale, P.R., and Lemckert, C.J., 2009. Influence of natural amphipod (Victoriopisa australiensis) (Chilton, 1923) population densities on benthic metabolism, nutrient fluxes, denitrification and DNRA in subtropical estuarine sediment. Hydrobiologia, 628(1), 95-105.

Dunn, R.J.K.; Welsh, D.T.; Jordan, M.A.; Waltham, N.J.; Lemckert, C.J., and Teasdale, P.R., 2012. Benthic metabolism and nitrogen dynamics in a sub-tropical coastal lagoon: microphytobenthos stimulate nitrification and nitrate reduction through photosynthetic oxygen evolution. Estuarine, Coastal and Shelf Science, 113 $272-282$

Dunn, R.J.K.; Welsh, D.T.; Lee, S.Y.; Lemckert, C.J.; Teasdale, P.R., and Meziane, T. 2008. Investigating the distribution and sources of organic matter in surface sediment of Coombabah Lake (Australia) using elemental, isotopic and fatty acid biomarkers. Continental Shelf Research, 28, 2535-2549.

Evans, P.R.; Ward, R.M.; Bone, M., and Leakey, M., 1998. Creation of temperate-climate intertidal mudflats: factors affecting colonization and use by benthic invertebrates and their bird predators. Marine Pollution Bulletin, 37(8), 8-12.

Ferguson, A.J.P.; Eyre, B.D., and Gay, J.M., 2003. Organic matter and benthic metabolism in euphotic sediments along shallow subtropical estuaries, northern New South Wales, Australia. Aquatic Microbial Ecology, 33, 137-154.

Folk, R.L., 1968. Petrology of Sedimentary Rocks. Austin, Texas: Hemphills, 170p.

Fonseca, G. and Netto, S.A., 2006. Shallow sublittoral benthic communities of the Laguna Estuarine System, South Brazil. Brazil Journal of Oceanography, 54(1), 41-54.

Fujii, T., 2007. Spatial patterns of benthic macroinfauna in relation to environmental variables in an intertidal habitat in the Humber estuary, UK: developing a tool for estuarine shoreline management. Estuarine, Coastal and Shelf Science, 75(1-2), 101-119.

Glassom, D. and Branch, G.M., 1997. Impact of predation by greater flamingos Phoenicopterus ruber on the macrofauna of two southern African lagoons. Marine Ecology Progress Series, 149, 1-12.

Gray, C.A.; McElligott, D.J., and Chick, R.C., 1996. Intra- and interestuary differences in assemblages of fishes associated with shallow seagrass and bare sands. Marine and Freshwater Research, 47(5), 723-735.

Gutteridge, Haskins, and Davey Pty. Ltd. (GHD), 2003. Coombabah Creek Environmental Inventory. Brisbane: GHD Pty Ltd. Report prepared for Gold Coast City Council, 316p.
Heip, C.H.R.; Goosen, N.K. Herman, P.M.J.; Kromkamp, J.; Middelberg, J.J., and Soetaert, K., 1995. Production and consumption of biological particles in temperate tidal estuaries. Oceanography and Marine Biology: Annual Review, 33, 1-149.

Heiri, O.; Lotter, A.F., and Lemcke, G., 2001. Loss on ignition as a method for estimating organic and carbonate content in sediments: reproducibility and comparability of results. Journal of Paleolimnology, 25(1), 101-110.

Hirst, A.J., 2004. Broad-scale environmental gradients among estuarine benthic macrofaunal assemblages of south-eastern Australia: implications for monitoring estuaries. Marine and Freshwater Research, 55(1), 79-92.

Hulscher, J.B., 1982. The oystercatcher Haematopus ostralegus as a predator of the bivalve Macoma balthica in the Dutch Wadden Sea Ardea , 70, 89-152.

Jones, A.R., 1987. Temporal patterns in the macrobenthic communities of the Hawkesbury Estuary, New South Wales. Journal Marine and Freshwater Research, 38(5), 607-624.

Jones, A.R.; Watson-Russell, C.J., and Murray, A., 1986. Spatial patterns in the macrobenthic communities of the Hawkesbury Estuary, New South Wales. Marine and Freshwater Research, 37(4), 521-543.

Jordan, M.A.; Welsh, D.T.; Dunn, R.J.K., and Teasdale, P.R., 2009 Influence of Trypaea australiensis population density on benthic metabolism and nitrogen dynamics in sandy estuarine sediment: a mesocosm simulation. Journal of Sea Research, 61(3), 144-152.

Kanaya, G. and Kikuchi, E., 2008. Spatial changes in a macrozoobenthic community along environmental gradients in a shallow brackish lagoon facing Sendai Bay, Japan. Estuarine, Coastal and Shelf Science, 78(4), 674-684.

Kanaya, G.; Suzuki, T., and Kikuchi, E., 2011. Spatio-temporal variations in macrozoobenthic assemblage structures in a riveraffected lagoon (Idoura Lagoon, Sendai Bay, Japan): influences of freshwater inflow. Estuarine, Coastal and Shelf Science, 92(1), 169-179.

Kennish, M.J., 2002. Environmental threats and environmental future of estuaries. Environmental Conservation, 29(1), 78-107.

Knight, J.M.; Dale, P.E.R.; Dunn, R.J.K.; Broadbent, G.J., and Lemckert, C.J., 2008. Patterns of tidal flushing within a mangrove forest: Lake Coombabah, South East Queensland Australia. Estuarine, Coastal and Shelf Science, 76(3), 580-593.

Kristensen, E., 2000. Organic matter diagenesis at the oxic/anoxic interface in coastal marine sediments, with emphasis on the role of burrowing animals. Hydrobiologia , 426(1), 1-24.

Lee, S.Y., 1999. The effect of mangrove leaf litter enrichment on macrobenthic colonization of defaunated sandy substrates. Estuarine, Coastal and Shelf Science, 49(5), 703-712.

McKindsey, C.W.; Archambault, P., and Simard, N., 2012. Spatial variation of benthic infaunal communities in baie de Gaspé (eastern Canada)—influence of mussel aquaculture. Aquaculture 356-357, 48-54.

Moreira, J.; Aldea, C., and Troncoso, J.S., 2010. Temporal dynamics of gastropod fauna on subtidal sandy sediments of the Ensenada de Baiona (NW Iberian Peninsula). Helgoland Marine Research, 64(4), 311-320.

Morrisey, D.J.; Underwood, A.J.; Howitt, L., and Stark, J.S., 1992. Temporal variation in soft-sediment benthos. Journal of Experimental Marine Biology and Ecology, 164(2), 233-245.

Mucha, A.P.; Vasconcelos, M.T.S.D., and Bordalo, A.A., 2004. Vertical distribution of the macrobenthic community and its relationships to trace metals and natural sediment characteristics in the lower Douro estuary, Portugal. Estuarine, Coastal and Shelf Science, 59(4), 663-673

Percival, J.B. and Lindsay, P.J., 1997. Measurement of physical properties of sediments. In: Mudroch, A.; Azcue, J.M., and Murdoch, P. (eds.), Manual of Physico-Chemical Analysis of Aquatic Sediments. Boca Raton: CRC, pp. 7-46.

Ponti, M.; Casselli, C., and Abbiati, M., 2010. Anthropogenic disturbance and spatial heterogeneity of macrobenthic invertebrate assemblages in coastal lagoons: the study case of Pialassa Baiona (northern Adriatic Sea). Helgoland Marine Research, 65(1), 25-42. 
Quammen, M.L., 1981. Use of exclosures in studies of predation by shorebirds on intertidal mudflats. The Auk, 98(4), 812-817.

Rainer, S., 1981. Temporal patterns in the structure of macrobenthic communities of an Australian estuary. Estuarine, Coastal and Shelf Science, 13(6), 597-620.

Rosa, S.; Granadeiro, J.P.; Vinagre, C.; França, S.; Cabral, H.N., and Palmeirim, J.M., 2008. Impact of predation on the polychaete Hediste diversicolor in estuarine intertidal flats. Estuarine, Coastal and Shelf Science, 78(4), 655-664.

Rossi, F.; Castelli, A., and Lardicci, C., 2006. Distribution of macrobenthic assemblages along a marine gradient in Mediterranean eutrophic coastal lagoons. Marine Ecology, 27(1), 66-75.

Ruello, N.V., 1975. Geographical distribution, growth and breeding migration of the eastern Australian king prawn Penaeus plebejus Hess. Australian Journal of Marine and Freshwater Research, 26(3), 343-354.

Sánchez-Moyano, J.E.; García-Asencio, I., and García-Gómez, J.C., 2010. Spatial and temporal variation of the benthic macrofauna in a grossly polluted estuary from southwestern Spain. Helgoland Marine Research, 64(3), 155-168.

Schrijvers, J.; Van Gansbeke, D., and Vincx, M., 1995. Macrobenthic infauna of mangroves and surrounding beaches at Gazi Bay, Kenya. Hydrobiologia, 306(1), 53-66.

Slomp, C.P.; Van Raaphorst, W.; Malschaert, J.F.P.; Kok, A., and Sandee, A.J.J., 1993. The effect of deposition of organic matter on phosphorus dynamics in experimental marine sediment systems. Hydrobiologia , 253(1-3), 83-98.

Snelgrove, P., 1999. Getting to the bottom of marine biodiversity: sedimentary habitats-ocean bottoms are the most widespread habitat on Earth and support high biodiversity and key ecosystem services. Bioscience, 49(2), 129-138.

Spilmont, N.; Meziane, T.; Seuront, L., and Welsh, D.T., 2009. Identification of the food sources of sympatric ghost shrimp
(Trypaea australiensis) and soldier crab (Mictyris longicarpus) populations using a lipid biomarker, dual stable isotope approach. Austral Ecology, 34(8), 878-888.

van Leussen, W., 1999. The variability of settling velocities of suspended fine grained sediment in the Ems estuary. Journal of Sea Research, 41(1-2), 109-118.

Welsh, D.T., 2003. It's a dirty job but someone has to do it: the role of marine benthic macrofauna in organic matter turnover and nutrient recycling to the water column. Chemistry and Ecology, 19(5), 321-342.

Wolff, W.J., 1987. Flora and macroinfauna of intertidal sediments. In: Baker, M.J. and Wolff, W.J. (eds.), Biological Surveys of Estuaries and Coasts. Cambridge, UK: Cambridge University, pp. 81-105.

Ysebaert, T. and Herman, P.M.J., 2002. Spatial and temporal variation in benthic macrofauna and relationships with environmental variables in an estuarine, intertidal soft-sediment environment. Marine Ecology Progress Series, 244, 105-124.

Ysebaert, T.; Fettweis, M.; Meire, P., and Sas, M., 2005. Benthic variability in intertidal soft-sediments in the mesohaline part of the Schelde estuary. Hydrobiologia, 540(1-3), 197-216.

Ysebaert, T.; Herman, P.M.J.; Meire, P.; Craeymeersch, J.; Verbeek, H., and Heip, C.H.R., 2003. Large-scale spatial pattern in estuaries: estuarine macrobenthic communities in the Schelde estuary, NW Europe. Estuarine, Coastal and Shelf Science, 57, 335-355

Ysebaert, T.; Meire, P.; Herman, P.M.J., and Verbeek, H., 2002 Macrobenthic species response surfaces along estuarine gradients: prediction by logistic regression. Marine Ecology Progress Series, $225,79-95$.

Zwarts, L. and Blomert, A.M., 1992. Why knot Calidris canutus take medium-sized Macoma balthica when six prey species are available. Marine Ecology Progress Series, 83, 113-128. 